\title{
David Oliver: The real world for NHS doctors
}

\author{
(C) $\mathbb{( 1 )}$ OPEN ACCESS
}

David Oliver, consultant in geriatrics and acute general medicine

Berkshire

Doctors' working lives, terms, and conditions aren't generally newsworthy. Most go through their careers miles from the media spotlight or industrial relations. Yet in England, recent stand-offs with the government over proposed new contracts have brought unaccustomed attention.

We've seen much public support, especially for the junior doctors' cause - but, among the reportage and the comments below articles, many have called for "these doctors" or "these NHS workers" to join "the real world."

This makes me wonder: in which "real world" don't we live? We work with people at their most vulnerable, who are ill, injured, or dying. We have many difficult conversations, including breaking bad news and trying to support and counsel patients' families. We meet people from every social stratum, including those facing deprivation, addiction, homelessness, or serious mental health problems. Most professions don't do this. So it can't be that.

Perhaps we' re seen as part of a "something for nothing" culture. Notions of fairness certainly include "getting out what you put in" and being rewarded only for endeavour, responsibility, and hard won skills. Doctors' competitive selection, the years of training and exams, objective criteria for progression, seniority, pay, and responsibility surely rule out that criticism-far more so than in most jobs.

Maybe the "real world" is one where no one is exempt from the "all in this together" pain of austerity. But, like the rest of the NHS, doctors took pay freezes from 2010 onwards; our earning power in real terms has dwindled. Although public sector pensions may seem generous by private standards, our scheme is fully funded, not subsidised: we pay at least $14 \%$ of our income to it.

Perhaps, by "the real world," commentators mean a 365 day a year service that mirrors modern service industries-hotels, retail, leisure. But emergency services, such as medicine, work all year round. Hospitals were frantic with activity right through Christmas, when much private industry wasn't working, judging by absent traffic and commuter trains.

Extreme real worlders probably think that no public sector occupation is the real world. Only profit and wealth creation have value and pay wages. But we are taxpayers too. Private contractors' track record of outperforming the state in core public services is patchy. And the sectors are totally interdependent. Business relies on education, transport, criminal justice, defence, waste collection - and healthcare. Much entrepreneurship is rooted in public-private partnership. Sometimes comments stem from resentment of doctors' continued high levels of trust and status. Most often, however, people use the "real world" to mean "a job or small business like mine." Worlds which, just like that of doctors, they freely chose to enter.

Like the rest of the NHS, doctors took pay freezes from 2010 onwards; our real terms earning power has dwindled

Competing interests: See www.bmj.com/about-bmj/freelancecontributors/david-oliver.

Provenance and peer review: Commissioned; not externally peer reviewed.

Follow David on Twitter, @mancunianmedic

Published by the BMJ Publishing Group Limited. For permission to use (where not already granted under a licence) please go to http://group.bmj.com/group/rights-licensing/ permissions

This is an Open Access article distributed in accordance with the Creative Commons Attribution Non Commercial (CC BY-NC 3.0) license, which permits others to distribute, remix, adapt, build upon this work non-commercially, and license their derivative works on different terms, provided the original work is properly cited and the use is non-commercial. See: http://creativecommons.org/licenses/by-nc/3.0/. 